\title{
SPOTLIGHT ON FUNDING FOR ENVIRONMENT AND ANIMALS IN CALIFORNIA
}

California foundation giving for environment and animals grew 5 percent between 2001 and 2006

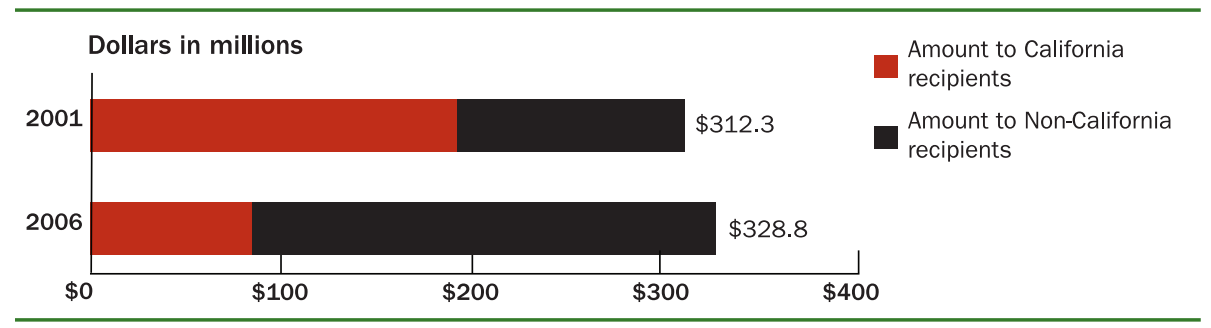

Note: In 2001 Foundation for Deep Ecology awarded more than $\$ 100$ million for the Environment including more than $\$ 70$ million to California recipients. In 2006 because overall giving totaled less than $\$ 600,000$ Foundation for Deep Ecology was not included in the sample. Based on grants awarded by 86 larger foundations.

Distribution of Larger Foundation Giving for Environment and Animals, 2006

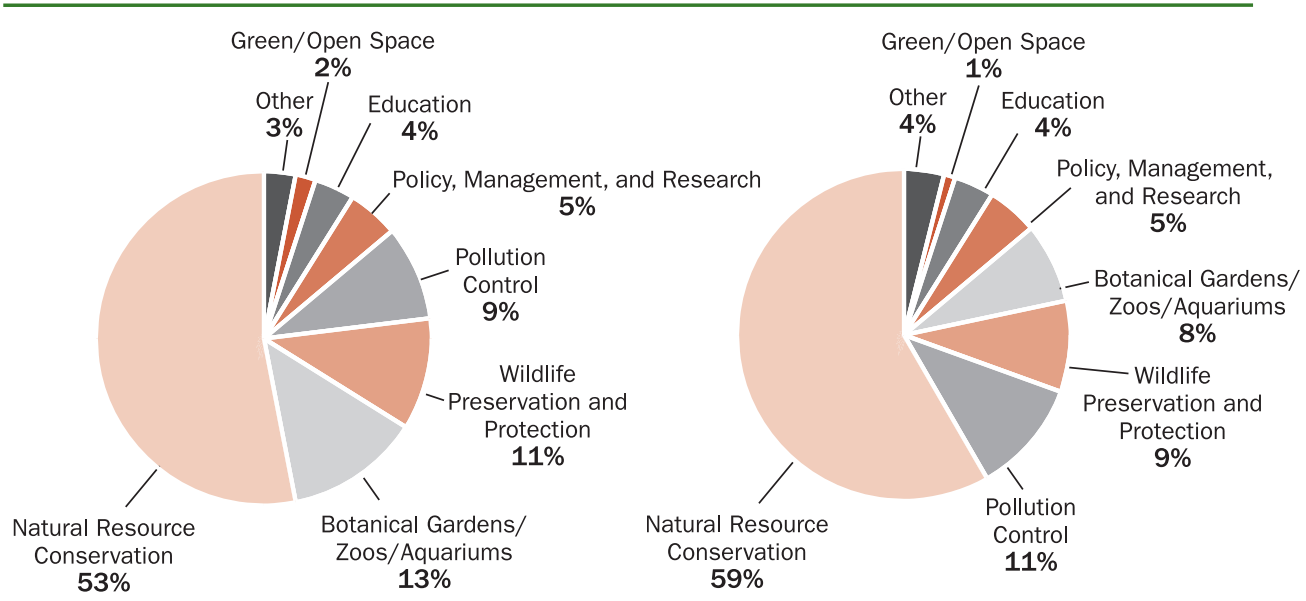

Total for All Recipients $=\$ 1.1$ billion

Total for California Recipients $=\$ 119.1$ million

Note: Based on grants awarded by 1,263 larger U.S. foundations.

Larger U.S. Foundation Giving for Environment and Animals in California by Types of Support in 2006

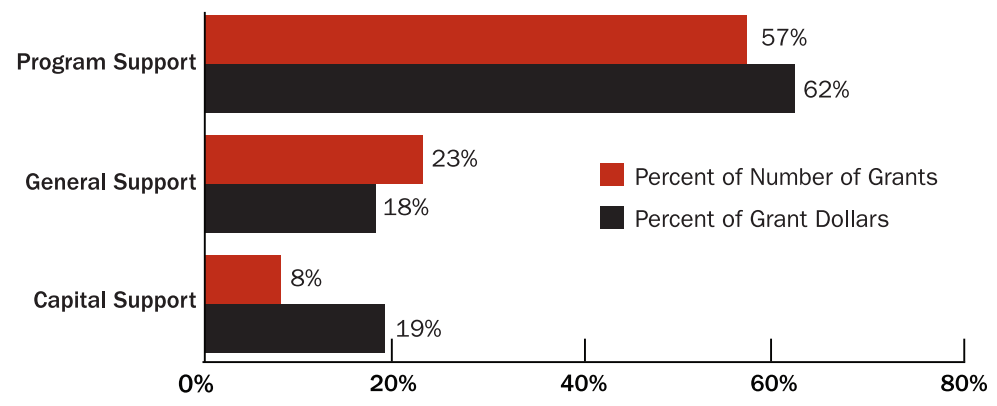

Note: Capital support includes endowment funds. Percentages may not add up to 100 . Some grants may be for multiple types of support, so they would be counted more than once. Based on grants awarded by 1,263 larger U.S. foundations.

\section{6 at a Glance \\ \$1.1 billion}

Amount given by all larger

U.S. foundations for environment and animals

\section{\$328.8 million}

Amount given by

larger California-based foundations for environment and animals

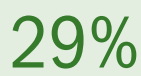

California foundations' share of all U.S. foundation giving for environment and animals

\section{$\$ 98.9$ million}

Amount given by all larger

U.S. foundations to California recipients for environment and animals

\section{Natural Resource Conservation}

Top priority for foundations funding for the environment in California 


\begin{tabular}{|c|c|c|c|c|}
\hline Foundation Name & City & Amount & $\begin{array}{l}\text { No. of } \\
\text { Grants }\end{array}$ & Environment and Animals Focus Areas \\
\hline 1. Gordon and Betty Moore Foundation & San Francisco & $\$ 120,488,875$ & 135 & $\begin{array}{l}\text { Seeks to preserve the Amazon Basin, protect North Pacific salmon ecosystems, and } \\
\text { improve marine management resources of coastal oceans. }\end{array}$ \\
\hline 2. William and Flora Hewlett Foundation & Menlo Park & $49,992,200$ & 131 & $\begin{array}{l}\text { Supports programs to save the great landscapes of the North American West; to help } \\
\text { build stronger constituencies for environmental protection in California; and to reduce } \\
\text { the environmental impacts of fossil-fuel energy systems. }\end{array}$ \\
\hline 3. David and Lucile Packard Foundation & Los Altos & $49,397,819$ & 176 & $\begin{array}{l}\text { Focuses on the challenge of sustainability through support for public policy reforms } \\
\text { and changes in private sector practices; also supports scientific activities to develop } \\
\text { essential knowledge and tools for addressing current and future priorities. }\end{array}$ \\
\hline 4. Energy Foundation & San Francisco & $26,468,229$ & 288 & $\begin{array}{l}\text { Seeks to assist in a transition to a sustainable future by promoting energy efficiency } \\
\text { and renewability. }\end{array}$ \\
\hline 5. Marisla Foundation & Laguna Beach & $13,028,700$ & 155 & $\begin{array}{l}\text { Primarily supports marine resources conservation with a geographic focus on the } \\
\text { western United States, Baja California, Chile, and the Western Pacific; also supports } \\
\text { the search for solutions to health threats caused by toxic chemicals. }\end{array}$ \\
\hline 6. Richard and Rhoda Goldman Fund & San Francisco & $10,706,000$ & 85 & $\begin{array}{l}\text { Supports three goals: 1) protect and restore California's environment; 2) reduce } \\
\text { impact of industry on the environment in California, nationally, and internationally; and } \\
\text { 3) protect threatened habitat internationally. }\end{array}$ \\
\hline 7. Peninsula Community Foundation* & San Mateo & $9,598,793$ & 101 & $\begin{array}{l}\text { Discretionary funding is provided to programs in San Mateo and Santa Clara } \\
\text { counties. Environment grants also come from donor-advised funds and supporting } \\
\text { organizations of the foundation. }\end{array}$ \\
\hline 8. Marin Community Foundation & Novato & $3,609,114$ & 48 & $\begin{array}{l}\text { Seeks to stimulate environmental awareness and knowledge, and to support } \\
\text { conservation of the natural environment of the community. }\end{array}$ \\
\hline 9. San Francisco Foundation & San Francisco & $3,582,635$ & 128 & $\begin{array}{l}\text { Supports improving environmental quality for those most in need; adopting and } \\
\text { implementing sound public environmental policy; and maintaining a healthy San } \\
\text { Francisco Bay/Delta ecosystem. }\end{array}$ \\
\hline 10. Community Foundation Silicon Valley* & San Jose & $3,558,436$ & 72 & $\begin{array}{l}\text { Discretionary funding is provided to programs in San Mateo and Santa Clara } \\
\text { counties. Environment grants also come from donor-advised funds and supporting } \\
\text { organizations of the foundation. }\end{array}$ \\
\hline
\end{tabular}

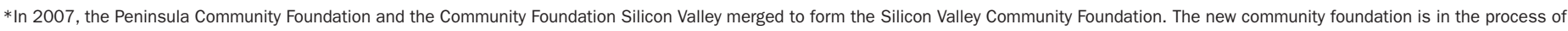
developing its approach to grantmaking. The above figures represent grants awarded by the foundations prior to the merger.

Top 10 Non-California Funders of the Environment and Animals in California, 2006

\begin{tabular}{lccc}
\hline \multicolumn{1}{c}{ Foundation Name } & State & Amount & $\begin{array}{c}\text { No. of } \\
\text { Grants }\end{array}$ \\
\hline 1. Annenberg Foundation & PA & $\$ 3,502,555$ & 13 \\
2. NoVo Foundation & NY & $3,000,000$ & 1 \\
3. Ford Foundation & NY & $2,786,648$ & 14 \\
4. Rockefeller Brothers Fund & NY & $2,475,000$ & 9 \\
5. Bill \& Melinda Gates Foundation & WA & $2,104,007$ & 2 \\
6. Offield Family Foundation & IL & $1,510,000$ & 5 \\
7. John D. and Catherine T. MacArthur & IL & $1,155,000$ & 6 \\
Foundation & & & \\
8. Beldon Fund & NY & $1,015,000$ & 7 \\
9. Gordon and Llura Gund Foundation & NJ & 995,720 & 1 \\
10. John Merck Fund & MA & 796,000 & 7 \\
\hline
\end{tabular}

Top 10 California Recipients of Foundation Funding for the Environment and Animals, 2006

\begin{tabular}{lccc}
\hline \multicolumn{1}{c}{ Recipient Name } & City & Amount & $\begin{array}{c}\text { No. of } \\
\text { Grants }\end{array}$ \\
\hline 1. Resources Legacy Fund & Sacramento & $\$ 12,868,234$ & 11 \\
2. University of California & Multiple locations & $5,771,270$ & 36 \\
3. Big Sur Land Trust & Carmel & $5,059,500$ & 4 \\
4. Tides Foundation & San Francisco & $4,435,000$ & 10 \\
5. Natural Resources Defense Council & San Francisco & $3,354,000$ & 10 \\
6. Trust for Public Land & Los Angeles, & $3,156,200$ & 27 \\
7. Zoological Society of San Diego & San Francisco & & \\
8. Earthjustice & San Diego & $2,185,350$ & 22 \\
9. Huntington Library, Art Collections, & Oakland & $2,100,720$ & 15 \\
and Botanical Gardens & San Marino & $2,000,000$ & 1 \\
10. Pacific Environment & San Francisco & $1,943,572$ & 9 \\
\hline
\end{tabular}

Source for all data: The Foundation Center. The Foundation Center indexes all of the grants of $\$ 10,000$ and more awarded by close to 1,200 of the nation's largest private and community foundations. This report is based on the Center's most recent (2006) sample, which includes 140,484 grants totaling $\$ 19.1$ billion. This report analyzes environment and animal welfare grants made to California recipients by 206 foundations, 86 that are based in California and 120 that are based outside of California, totaling $\$ 98.9$ million.

Spotlight on Funding for Environment and Animals in California is available at: foundationcenter.org/gainknowledge.

For more information, contact Janet Camarena, director of the Foundation Center's San Francisco office at (415) $397-0902$ ext. 100 or e-mail jfc@foundationcenter.org. 